brought it into contact with the skin at the most exposed parts, especially at the wrists. The association of the condition with moisture is confirmed by the fact that one or two boys in the same employment received their overcoats about a fortnight earlier but only exhibited symptoms on the same day as the others, Nov. 23rd being the first really wet day since that time. An infusion of the cloth was made. It had an acid reaction and a sweet astringent taste and on analysis it was found to contain zinc chloride.

Birmingham.

\section{DIPHTHERIA BACILLI IN URINE.}

By H. W. L. BARLOW, M.B. OXON., M.R.C.S. ENG., D.P.H.

IN view of the observations of Captain F. Smith, R.A.M.C., on diphtheria bacilli in the urine of guinea-pigs ${ }^{3}$ the following case may be of interest.

The patient, a well-nourished single woman, aged nineteen years, was admitted to Brighton Isolation Hospital on Jan. 8th, 1898, with patches of yellowish membranous exudate containing Klebs-Löffler bacilli on both tonsils, together with moderate pyrexia, a relatively slow but hightension pulse, and smoky urine. All else was normal: there were no signs of cardiac hypertrophy, there had never been any cedema, and there were no retinal hæmorrhages. She had had small-pox in infancy and influenza a year or two ago, but no other illness except occasional attacks of headache and vomiting. Dark-coloured urine was first noticed on the morning of admission-i.e., the third day. It was acid, it contained both albumin and blood, and it showed urates, casts, and bacilli, some of the latter resembling those of diphtheria. Serum cultures plated out on agar showed on the third, fourth, eighth, twelfth, thirteenth, sixteenth, and twenty-first days of the disease a diphtheria-like organism besides some other forms. This bacillus disappeared as the nephritis wore off (no bacilli and very little albumin were found on the fifteenth day) and reappeared for a short time with a relapse on the sixteenth day, ultimately disappearing altogether. In one doubtful instance only did cultures from other urines in the ward show an organism at all similar to this. A pure culture obtained by plate cultivation was compared step by step with similar cultures of the same age of long Klebs-Löffler bacilli from a fatal case, of Hoffmann's pseudo-diphtheria bacillus, and of a doubtful form isolated from the throat from another case. The last-named proved quite distinct and need not be further considered. The points of difference between the organism from urine and the Klebs-Löffler bacillus did not amount to more than are usually present between the three or four different types of diphtheria bacilli in throat swabs. These bacilli were just as characteristically irregular in form, but they were shorter and apparently of more rapid growth. Their distinguishing features were, first, no growth on gelatin at room temperature; secondly, alkaline glucose broth acidified within twenty-four hours; thirdly, each bacillus showed three or four granules apiece when stained with methylene blue and bismarck brown; and, fourthly, both colonies and streak cultures only differed from those of Klebs-Löfler in minor details. Owing to an accident their pathogenicity to guinea-pigs was not tested. A remarkable point is that cultures could be obtained from the acid urinary sediment after standing for eight days at the room temperature; but this does not, as was first thought, militate against the organisms being diphtheritic, for Klebs-Löffle bacilli not only live but multiply in faintly acid peptone broth containing urea if kept at $37^{\circ} \mathrm{C}$. The bacilli in the throat swab were both long and short, the latter being most persistent. The urine always reacted acid to litmus to a degree not determined.

\begin{tabular}{|c|c|c|c|c|c|c|}
\hline \multicolumn{3}{|c|}{$\begin{array}{l}\text { Day of } \\
\text { Disease. }\end{array}$} & $\begin{array}{l}\text { Amount in } \\
24 \text { hours. }\end{array}$ & $\begin{array}{l}\text { Grammes } \\
\text { nitrogen. }\end{array}$ & $\begin{array}{l}\text { Grammes } \\
\text { albumin. }\end{array}$ & $\begin{array}{l}\text { Grammes } \\
\text { chlorine. }\end{array}$ \\
\hline 4 th & $\cdots$ & ... & 425 c.c. & $2 \cdot 8$ & $5 \cdot 1$ & 0.47 \\
\hline 8th & $\ldots$ & $\ldots$ & 760 c.c. & $4 \cdot 4$ & $7 \cdot 6$ & 0.98 \\
\hline 19th & $\ldots$ & $\ldots$ & 850 c.c. & $7 \cdot 4$ & $4 \cdot 25$ & $1 \cdot 36$ \\
\hline 36 th & $\ldots$ & $\cdots$ & 1650 c.c. & $9 \cdot 1$ & $4 \cdot 9$ & $4 \cdot 45$ \\
\hline
\end{tabular}

1 The LAYCET, Nov. 19th, $18 \subseteq 8$.
Some kind of micro-organism might nearly always be found in urine and it would not be supposed to have reached it through the kidney unless all other paths were closed. Though cleanliness was ensured it was manifestly impossible in this case to take all the precautions which Captain Smith adopted and it must remain to that extent inconclusive. The presence of other forms shows that contamination did occur, but they were variable and the diphtheria constant and if not explained by a kidney infection the casual coexistence of nephritis and bacilli on seven or eight occasions throughout a fortnight or more would remain a rather curious coincidence.

Diphtheritic nephritis, always rare, is decreasing year by year in the metropolitan hospitals. During the last three years it occurred in only 0.77 per cent. of over 13,000 cases and, taking 1897 alone, the percentage is less than half thisnamely, 0.34 per cent. - while that of albuminuria remains about 45 per cent. Bacilli have been found post mortem in the kidney by Kanthack and others, but they do not seem to be always associated with nephritis, and if found in other cases their presence is evidently exceptional.

Urmston.

\section{THE TREATMENT OF WHOOPING-COUGH}

\section{BY G. ARBOUR STEPHENS, M.D., B.Sc. LOND.}

I HAVE lately been investigating the subject of whooping* cough, by which I mean the very infectious disease characterised by a convulsive cough terminating in the readily recognised "whoop." In this investigation I have been considerably assisted. by the fact that Mr. Hubert Thomas placed a large number of the cases of this complaint which existed extensively in his district at my disposal. My attention was particularly drawn to the subject by a small experiment upon myself. When I had an attack of pharyngitis I found that by tickling the external auditory meatus or the tympanum I produced a cough with the characteristic "whoop." This led me to inquire into the state of the patients' ears in cases of whooping-cough and in nearly every case I found that they either had pain in their ears, as evidenced by the fact that they resented their mothers' washing or even touching those organs, or else that there existed a semi-fluid discharge which in some cases had been present for some time. Having found such a persistent sign or symptom I decided to find out whether treatment applied locally might ease the pain or diminish the discharge and by so doing modify or terminate the course of the disease.

The course of treatment I decided on was as follows. I syringed out the ears night and morning with lukewarm boric lotion or water and applied to the meatus and tympanum a paint consisting of $23 \mathrm{gr}$. of hydrochlorate of cocaine, 4 drachms of glycerine, 20 minims of solution of perchloride of mercury, and water to 1 ounce. The result of this treatment was that in every case the patient was benefited and the whooping-cough was got rid of. In many cases, in addition to what I consider the essential symptoms of whooping-cough, there were present bronchitis, pharyngitis, or laryngitis. These, I need hardly say, did not yield to the treatment above described, and in some cases they persisted for several days after the "whoop" had disappeared. As has been often noticed by other observers the whoopingcough followed in the wake of measles, and in those cases which did succeed measles there was nearly always found a discharge which had continued from the prior attack of measles. In the first few cases I had some trouble in introducing such a novel form of treatment as a substitute for the more othodox bottle of medicine, but having got the first few patients better their friends and relations paved the way for the others. The following are a few of the cases :-

CASE 1.-A boy, aged four years, had had cough for two or three weeks and a discharge from the ears for eleven montbs. With the cough there was vomiting. The mother. "could not touch the ears" owing to the pain. The ears were syringed and painted. The child slept better the same night and "whooped" much less the next day, when the ears were again syringed and painted. On the third day the child was not very bright and the tongue was furred, but the "whoop" continued to improve and the pationt had had a very good night. I ordered a dose of mercury with chalk. The child was decidedly better on the fourth day, having 